\title{
Evolution of Ukrainian Annual National Program since 2015 as response to changing information environment and hybrid threats
}

\author{
Iryna Izhutova ${ }^{A}$
}

Received: January 26, 2020 | Revised: February 28, 2020 | Accepted: February 29, 2020

DOI: $10.33445 /$ sds.2020.10.1.11

\begin{abstract}
This article aims at researching the evolution and change of structure and content of the Ukrainian Annual National Program (ANP) since 2015 as response to ongoing hybrid warfare and addressing new hybrid threats. Strategic Communications are in focus of the research. It is underscored the flexibility of the program in line with ongoing reforms in Ukraine which cover all the spheres.
\end{abstract}

Keywords: strategic communications, annual national program, hybrid threats, information environment.

\section{Introduction}

\section{Research novelty}

In 2015, in view of temporary occupation of Crimea by Russian Federation (RF), the critical situation in several regions of Donetsk and Luhansk oblasts, Russian aggression against Ukraine, the need of development of a new approach to tailoring the Annual National Program of Ukraine-NATO cooperation (ANP) raised [1] because this document is a general plan of reforms which Ukraine needs to realize and implement.

Ukraine had to change the ANP in order to ensure protection of national interests and security of Ukraine in line with use of NATO and NATO nations practical assistance; increase its defence level to fight against RF aggression by reforming the defence and security sector and defence industry under the NATO standards.

So, the year of 2015 was a milestone for the Ukrainian ANP. Then, it has been changing and evolving in line with reforms and all the processes undergoing in Ukraine.

The whole situation in Ukraine and around it pushed the reform process and fostered integration of new elements in main documents.
This research covers this transformation processes in terms of implementation and realization of strategic communications within the Annual National Program. We try to analyze and evaluate reforms; find positive and negative points.

\section{Recent research and publications analysis}

The issue of strategic communications in the interests of the national security and defence has been considered in studies of G.Pocheptsov, V.Kopiyka, V.Lipkan, D.Dubov, A.Barovska, O.Kushnir, Ye.Makarenko, I.Panteleichuk, etc., meanwhile, the analyze of the issue of the Annual National Program was never included in their researches.

They focus on research of terms and definitions of strategic communications, experience of NATO nations in implementing strategic communications, necessity of consolidation of strategic communications efforts in fighting against current hybrid threats, strategic communications in business, commerce and public administration but they do not touch the issue of realization of activities under the Annual National Program.

\footnotetext{
A National Defence University of Ukraine, Chief of Training Section, Education and Research Centre for Strategic Communications in Security and Defence Sector, 28, Vozduhoflotsky, ave, Kyiv, 03049, Ukraine, e-mail: perevod_vu@ukr.net, ORCID: 0000-0002-26147014
} 


\section{Material and Method}

The aim of this article is to research the evolution of the Annual National Program in terms of the strategic communications since 2015.

\section{Results and discussion}

2.1. Thus, the Annual National Program 2015 does not contain any information about strategic communications as this term was just appearing in Ukraine. Meanwhile the mi-term objective outlined in this ANP 2015 was:

to complete the process of formation of training and advanced training system of public affairs (PA) officers at the National Defence University of Ukraine and Military Institute of the Kyiv Taras Shevchenko National University;

to improve forms and methods of cooperation of military administration authorities with journalists, mass media in line with Euro-Atlantic standards; and

to ensure media coverage of information about service personnel resettlement programs [1].

In view of these statements we see that the ANP 2015 just contains one component of the strategic communications such as the Public Affairs and omits the other components failing to develop the whole system of the strategic communications in the country. The whole system is a pre-requisite for a harmonic existence of the state and effective fighting against the hybrid threats.

The situation in and outside Ukraine, evolving non-conventional and hybrid activities resulted in appearance of the NATO-Ukraine Strategic Communications Partnership Roadmap (the Roadmap) signed by NATO Secretary Jens Stoltenberg and Ukraine's National Security and Defence Council (NSDC) Secretary Oleksandr Turchynov in September 2015 [2].

The Strategic Communications Partnership aims to enhance the capabilities of the Ukrainian authorities in the field of Strategic Communications, assist the development of Ukraine's Strategic Communications culture and maintain the highest standards of accuracy and ethics to ensure the credibility and efficiency of Ukraine's government communications. Activities under the Roadmap Implementation
Plan are tailored to achieve these goals and focus on: capacity-building in various communications disciplines, training capacity development, public diplomacy, and research in the sphere of communications [3]. This new document influenced the content of many other Ukrainian documents which were supplemented by strategic communications. The Annual National Program also reacted to this document.

2.2. Next year (2016) the Chapter 1 , Section 1.5 of the ANP is focused on information distribution about Ukraine-NATO cooperation. This activity should be aimed at raising awareness about advantages of this cooperation [4].

Ukraine-NATO cooperation in strategic communications becomes especially important in view of RF information warfare against Ukraine, NATO, and European Union. The Roadmap plays a key role in formation and development of the Ukrainian strategic communications capabilities supported by consultative and practical assistance [4].

Among mid-term objectives are UkraineNATO cooperation information distribution at regional and local levels; enhancement of fighting against disinformation and propaganda; strengthening the capabilities of the Ukrainian officials in strategic communications by means of consultative support which is stipulated in the Roadmap Implementation Plan [4].

2016 objectives are also information distribution; development of strategy for fighting against disinformation and propaganda in Ukraine considering the NATO experience; as well as implementation of the Roadmap Implementation Plan. The Ukrainian mass media should provide information about NATO and Ukraine-NATO partnership. Following this new ANP, the strategic communications system should be designed in Ukraine in assistance of 
the NATO experts and some ministries are assigned to fulfil the Roadmap provisions [4].

The Chapter 2, Section 2.2, Subsection 2.2.3 defines the Ukrainian Armed Forces reform tasks:

to optimize structure and strength;

to modernize armament and make it technically sound;

to improve troops training system;

to reorganize the system of operations and logistic support;

to enhance troops (forces) capabilities to accomplish tasks assigned;

to develop the strategic communications system,

to ensure information and cyber security of troops; and

to approach to the NATO standards [4].

So, in 2016, the strategic communications were integrated in the main reform plan of Ukraine such as the Annual National Program both at national level and within the Ministry of Defence of Ukraine particularly. And the strategic communications had to foster fighting against hybrid threats. Moreover, since 2016, even NATO and the European Union have identified countering hybrid threats as a priority for cooperation [5].

NATO defines that hybrid threats are diverse and ever-changing, and the tools used range from fake social media profiles to sophisticated cyber attacks, all the way to overt use of military force and everything in between. Hybrid influencing tools can be employed individually or in combination, depending on the nature of the target and the desired outcome. As a necessary consequence, countering hybrid threats must be an equally dynamic and adaptive activity, striving to keep abreast of variations of hybrid influencing and to predict where the emphasis will be next and which new tools may be employed [5].

In March 2016, the Ministry of Information Policy together with the NSDC and the NATO Information and Documentation Centre in Ukraine held the first meeting of the working group on developing the structure of strategic communications and coordination mechanisms. A plan for the implementation of the Roadmap for the short term has been developed. In some ministries, posts of advisers on strategic communications were introduced, to which foreign experts were invited. However, it would be an exaggeration to talk about the effective conduct of strategic communications by the Ukrainian government officials at the present time, especially with regard to the adherence to the "sole voice" policy in the international environment [9].

In 2016 defence review ended by the tailoring a principally new Strategic defence bulletin until 2020. The Strategic Defence Bulletin of Ukraine (the SDB) is a document of defence planning elaborated under the results of the defence review in order to ensure the main directions of the implementation of military policy of Ukraine and the development of defence forces until 2020.

The Bulletin is aimed at ensuring practical implementation of the Military Doctrine of Ukraine and the Concept of Development of Security and Defence Sector of Ukraine; defines strategic and operative goals of the defence reform and expected results of their achievement taking into account topical military and political threats and challenges. The document provides for the active participation in the implementation of the Common Security and Defence Policy of the European Union and active cooperation with NATO in the achievement of criteria necessary for the full membership in NATO [6].

It contains the reform elements included in the ANP 2016. Consequently, the Item 2.2 of the SDB states that within ongoing active democratic, social, state legal transformations in Ukraine there is a strong political responsibility to ensure the national defence [7].

According to the SDB, in order to achieve the harmonization with the Euro-Atlantic norms Ukraine will enhance the inter-ministerial coordination in national security and defence, intelligence coordination, cooperation in monitoring and environment evaluation, improve command and control and communications systems, and ensure development of the system of cyber protection and strategic communications [7]. 
Among operation objectives of the SDB, there is one to be mentioned. This the operation objective 1.7 Formation and development of capabilities of the defence forces in strategic communications as a part of inter-ministerial strategic communications system aimed at supporting formation and realization of the security and defence policy of Ukraine, as well as achievement of the national defence goals. The estimated result is to develop communications capabilities at strategic, operative, and tactical levels which integrate and support strategic communications at all levels of planning and security and defence policy realization [7].

In November 2016 the experts brought together to discuss the results of the ANP 2016 and mentioned some progress in reforms implementation due to this document but also found some weak points which needed to find some new approaches to development of the ANP [8].

So, the year of 2016 was a milestone for strategic communications due to its integration in all key security and defence documents.

2.3. In 2017, the ANP underscores that Ukraine-NATO cooperation in strategic communications is especially important in the context of RF hybrid warfare against Ukraine. Again, it is stressed the importance of the Roadmap implementation. The Roadmap Implementation Plan should increase and strengthen the level of communication cooperation of state authorities in national strategic tasks and reforms [10].

At the state level, the main strategic communications Partnership goals are:

to develop state authorities capabilities in strategic communications at strategic and operative levels through consultative and practical assistance;

to support cooperation of Ukraine with appropriate strategic communications experts;

to contribute to development of strategic communications culture (it was exceptionally stated in the Roadmap) in Ukraine at institutional level, establish closer cooperation with non-government organizations and foster development of strategic communications in the interests of Ukraine; and to achieve ever-highest standards for support of the state communicative policy [10].

In the context of enhancement of communicative influence it should be developed the system bringing together communications at the state policy level and be aimed at:

shifting the state approach from simple information distribution

to

hear/consult/involve;

defining the mechanism of communication coordination among state authorities (crossagency coordination); and

implementing a new approach to crisis communications from crisis response to risks (problems) management [10].

The mid-term goals include:

development of effective system of the public broadcasting;

reform of state and public printed media;

development of coordination interministerial mechanism of information operations;

reform of government communications;

information reintegration of separate regions of Donetsk and Luhansk oblasts;

development of ministerial and governmental /inter-ministerial system of strategic communications;

development of strategic communications capabilities in national defence and security;

development of public diplomacy;

development and realization of national strategy of Ukraine in strategic communications; development of system of professional training of strategic communications experts;

enhancement of information cooperation with partner nations.

Among 2017 top priorities is development of state strategic communications educational standard and plan of its implementation [10].

Moreover, the Annual National Program 2017 assigns tasks to the ministries and departments within the state. Thus, the system of professional strategic communications training of leaders and experts of the Ministry of Defence and General Staff of the Armed Forces of Ukraine should be developed at the National Defence University. 
2.4. In 2018, the ANP already has a particular sub-paragraph 1.2.1.3. Strategic Communications.

According to it, the main goals and mid-term objectives correspond to those mentioned in previous ANPs.

2018 priorities are:

to continue implementation of the Roadmap;

to develop policy and coordination mechanism in public diplomacy (effectiveness of public diplomacy we analyzed in our previous article [14];

to develop capabilities in state crisis communications;

to reform state communications; and

to develop the model of education system of the state strategic communications and develop plan of its implementation [11].

In terms of the Ministry of Defence of Ukraine the section 2.1.5. Reforms of the Armed Forces of Ukraine states the necessity to develop strategic communications system and ensure information and cyber security of troops [11]. Moreover, other Ministry should participate in the development of the state strategic communications system development.

From year to year we observe the augmentation and diversification of strategic communications tasks and matching of declared tasks with actual and real developments and achievements. The ANP becomes more practical and results-based.

2.5. In 2019, the ANP contains sub-section 1.2.2 National System of Strategic Communications (in 2018 a particular strategic communications sub-section was introduced and in 2019 there is an understanding of the whole national system of strategic communications in Ukraine). There are defined 5 top priorities which include:

reform of government communications;

development of the model of education system of the state strategic communications and develop plan of its implementation;

development of strategic communications capabilities in national security and defence;

initialization of Ukraine-NATO system strategic communications in security of energy supply of Ukraine and its neighbouring countries in order to respond quickly to energy supply threats, work out agreed collective actions and system solutions for minimization of such threats; and

comprehensive campaigns in order to popularize Ukraine in the world [12].

In terms of the Ministry of Defence of Ukraine, the subsection 2.2.5. Development of strategic communications capabilities of the defence forces.

The Ministry of Defence tasks include:

to adapt and implement policies, doctrines and practices of the NATO nations strategic communications within the Ministry of Defence and Armed Forces of Ukraine; and

to raise the level of the Ukrainian Armed Forces personnel awareness of aim and tasks of the strategic communications (this task foresees the integration of strategic communications in education and training of the military personnel at all levels and establishment of the strategic communications training centre at the National Defence University of Ukraine) [12].

2.6. The ANP 2020 is still pending its presidential signing, meanwhile, he Government endorsed the Annual National Program (ANP) for 2020 which had been elaborated under the auspices of the NATOUkraine Commission and is based on a methodology of measured results, focuses on human security, contains a monitoring mechanism for the implementation, and builds on the principles, structure and content of NATO membership action plans of countries that had become members of the Alliance [13].

"Our Government has included in its Action Program an ambitious goal: in five years Ukraine should achieve the criteria for joining the NATO. What kind of Ukraine we will have when it achieves the level of NATO standards? It is a state for which the safety and well-being of the citizen are the focus. The state that is capable of defending its human-centric principles," said Prime Minister of Ukraine Oleksiy Honcharuk [13].

In addition, the document was first developed with applying the international Results-Based Management (RBM) method. Such a methodology is used in the preparation 
of similar strategic documents in NATO member states, the World Bank, and the UN [13].

The ANP envisages both security and defence sector reforms as well as democratic transformations within the country. Among the top priority reforms are, in particular, bringing to compliance the entire defence forces management system, strategic and operational (combat) management, communications, intelligence and surveillance aligned with NATO standards and compatibility, introducing democratic civilian control, providing conditions for participation of Ukrainian enterprises in NATO multinational projects in the field of development and production of weapons and equipment, etc. Among others, inter alia, are a shaped market economy, a transparent tax system, effective scientific cooperation between Ukraine and countries-members of the NATO and the EU, a counter-terrorism system that makes Ukraine a reliable partner in the international security environment, the development of a system of national sustainability and protection of critical infrastructure, so on [13].

The Annual National Program is modelled as close as possible on the content and principles of the NATO Membership Action Plan (MAP) and has the same structure of five sections: I. Political and Economic issues; II. Defence/Military Issues; III. Resource issues; IV. Security issues; V. Legal issues [13].

The ANP is a key instrument for Ukraine's integration into NATO and a roadmap for reforms aimed to translate Alliance standards and principles into reality. It was elaborated by the Alliance in 2008, when at the Bucharest Summit, allies welcomed Ukraine to NATO membership. This year, the implementation of the ANP is aimed at achieving goal 17.2 of the Cabinet of Ministers of Ukraine Action Program "Ukraine meets the principles and criteria necessary to acquire membership in the North Atlantic Treaty Organization" [13].

\section{Conclusions}

The article researches the evolution and change of structure and content of the Ukrainian Annual National Program (ANP) since 2015 as response to ongoing hybrid warfare and addressing new hybrid threats. Strategic Communications are in focus of the research. It is underscored the flexibility of the program in line with ongoing reforms in Ukraine which cover all the spheres.

The ANP 2015 did not even contain the term strategic communications. It dealt only with its component - Public Affairs but later in the context of comprehensive reforms in the state a particular subsection appeared in the Annual National Program.

Moreover, the ANP has become more practical and result-based one. Any action or activity is evaluated by means of the measurement of performance and measurement of effectiveness; is correlated with ongoing reforms and transformation processes in other ministries and departments and country as whole.

\section{References}

1. Ukaz Prezydenta Ukrayny Pro zatverdzhennya Richnoy natsionalnoy programy spivrobitnitstva Ukraina - NATO na 2015 rik № 238/2015 vid 23 kvitnya 2015 roku. URL: https://zakon.rada.gov.ua/laws/show/238/20 15. [In Ukrainian]

2. Dorozhnya karta Partnerstva u sferi strategichnykh komunikatsiy mizh Radoyu natsionalnoy bezpeky $\mathrm{i}$ oborony Ukrayny ta Mizhnarodnim sekretariatom NATO. URL: http://mfa.gov.ua/mediafiles/sites/nato/files/ Roadmap_Ukr.pdf. [In Ukrainian]

3. NATO Information and Documentation Centre (NIDC). URL: https://www.nato.int/cps/uk/natohq/topics_6 4610.htm?selectedLocale=en.

4. Ukaz Prezydenta Ukrayny Pro zatverdzhennya Richnoy natsionalnoy programy spivrobitnitstva Ukraïna - NATO na 2016 rik №45/2016 vid 12 lyutogo 2016 roku. URL: 
https://www.president.gov.ua/documents/45 2016-19779. [In Ukrainian]

5. Cooperating to counter hybrid threats. URL: https://www.nato.int/docu/review/articles/20 18/11/23/cooperating-to-counter-hybridthreats/index.html.

6. President approved Strategic Defence Bulletin of Ukraine. URL: https://nato.mfa.gov.ua/ en/news/48211-prezident-zatverdivstrategichnij-oboronnij-byuleteny-ukrajini.

7. Ukaz Prezydenta Ukrayny Pro rishennya Rady natsionalnoy bezpeky i oborony Ukrayny №240/2016 vid 20 travnya 2016 roku "Pro Strategichniy oboronniy byuleten Ukrayny". URL:

https://www.president.gov.ua/documents/24 02016-20137. [In Ukrainian]

8. Ekspertne obgovorennya poperednikh rezultativ gromadskogo monitoringu RNP-2016 (pidsumky). http://www.ieac.org.ua/news/ item/44-ekspertne-obhovorennya-popere dnikh-rezultativ-hromadskoho-monitorynhurnp2016-pidsumky. [In Ukrainian]

9. Hybrid threats to Ukraine and public security. The EU and Eastern Partnership experience Analytical report Kyiv - 2018. URL: https://www.civic-synergy.org.ua/wpcontent/uploads/2018/04/blok_XXI-engllast.pdf.
10. Ukaz Prezydenta Ukrayny Pro zatverdzhennya Richnoy natsionalnoy programy pid egidoyu Komisiï Ukraïna - NATO na 2017 rik №103/2017 vid 8 kvitnya 2017 roku. URL: https://www.president.gov.ua/documents/10 32017-21670. [In Ukrainian]

11. Ukaz Prezydenta Ukrayny Pro zatverdzhennya Richnoy natsionalnoy programy pid egidoyu Komisiï Ukraïna - NATO na 2018 rik №89/2018 vid 28 bereznya 2018 roku. URL: https://www.president.gov.ua/documents/89 2018-23882. [In Ukrainian]

12. Ukaz Prezydenta Ukrayny Pro zatverdzhennya Richnoy natsionalnoy programy pid egidoyu Komisiï Ukraïna - NATO na 2019 rik №117/2019 vid 10 kvitnya 2019 roku. URL: https://www.president.gov.ua/documents/11 72019-26450. [In Ukrainian]

13. Government approves a new quality UkraineNATO Annual National Program. URL: https://www.kmu.gov.ua/en/news/uryadshvaliv-richnu-nacionalnu-programu-ukrayinanato-novoyi-yakosti.

14. Izhutova, I. (2019). Ukrainian Strategic Communications and martial law. Journal of Scientific Papers "Social Development and Security", 9 (5), 127. https://doi.org/10.33445/ sds.2019.9.5.8. URL: http://www.paperssds.eu/index.php/JSPSDS/ article/view/145. 